\title{
Molecular modeling studies on dengue and West Nile Virus NS2B/NS3 protease inhibitor interaction K Wichapong*1,2, S Pianwanit ${ }^{1}$, S Kokpol ${ }^{1}$ and W Sippl ${ }^{2}$
}

\author{
Address: ${ }^{1}$ Department of Chemistry, Faculty of Science, Chulalongkorn University, Bangkok, 10330, Thailand and ${ }^{2}$ Department of Pharmaceutical \\ Chemistry, Martin-Luther-University of Halle-Wittenberg, 06120, Halle (Saale), Germany \\ * Corresponding author
}

from 4th German Conference on Chemoinformatics

Goslar, Germany. 9-II November 2008

Published: 5 June 2009

Chemistry Central Journal 2009, 3(Suppl I):P55 doi:10.II86/I752-I53X-3-SI-P55

This abstract is available from: http://www.journal.chemistrycentral.com/content/3/SI/P55

(C) 2009 Wichapong et al; licensee BioMed Central Ltd.

Dengue Virus (DV) and West Nile Virus (WNV) are causes of severe public-health problems in many countries. Neither effective human vaccines nor drugs against both DV and WNV are available. NS2B (an essential cofactor) together with NS3 protease, which is a vital enzyme for the viruses in the replication cycle, is currently focused as the promising enzyme target for drug development. However, the active enzyme-inhibitor complex of DV is not yet experimentally available. Therefore, 3D structure of the DV's enzyme was built using the related WNV NS2B/NS3 structure as a template (2FP7.pdb) [1]. The DV model and 2FP7.pdb (WNV-X) were subjected to molecular dynamics (MD) simulations. MD simulations reveal the important of NS2B for interacting with both NS3 protease and P2 subsite of inhibitor. The final MD snapshot of DV model and WNV-X were employed for GRID field calculations. Results show bigger $\mathrm{N}^{+}$and $\mathrm{OH}$ fields at the $\mathrm{S} 1$ pocket of DV model than those of WNV-X implying the importance of the electrostatic or H-bond interaction at the S1 pocket than that of WNV. On the other hand, the Dry field at the S1 pocket of WNV-X is larger than that of DV model indicating the relevance of hydrophobic interaction at this pocket for WNV. In addition, MD simulations of the NS2B/NS3 protease of $\mathrm{WNV}$ and DV complexed with Bz-Nle-Lys-Arg-Ala-H (most selective inhibitor, $\mathrm{Ki}=193.00 \mu \mathrm{M}$ for DV and IC50 $=4.6 \mu \mathrm{M}$ for WNV) $[2,3]$ were also carried out. Results reveal that Ala$\mathrm{P} 1$ of the inhibitor is not able to make favourable electrostatic interactions at the $\mathrm{S} 1 / \mathrm{S} 2$ pockets of DV. The simulations showed also that both S1-P1 and S2-P2 interactions are important for inhibiting the DV protease whereas in case of the $\mathrm{WNV}$ protease the interaction at the S1-pocket is less important.

\section{References}

I. Erbel P, Schiering N, D'Arcy A, Renatus M, Kroemer M, Lim SP, Yin Z, Keller TH, Vasudevan SG, Hommel U: Nat Struct Mol Biol 2006, 1 3:372-373.

2. Yin Z, Patel SJ, Wang WL, Chan WL, Ranga Rao KR, Wang G, Ngew X, Patel V, Beer D, Knox JE, Ma NL, Ehrhardt C, Lim SP, Vasudevan SG, Keller TH: Bioorg Med Chem Lett 2006, 16:40-43.

3. Knox JE, Ma NL, Yin Z, Patel SJ, Wang WL, Chan WL, Ranga Rao KR, Wang G, Ngew X, Patel V, Beer D, Lim SP, Vasudevan SG, Keller TH: J Med Chem 2006, 22:6585-6590. 